\title{
РОССИЙСКАЯ ФЕДЕРАЦИЯ НА МЕЖДУНАРОДНОМ РЫНКЕ ИНТЕЛЛЕКТУАЛЬНОЙ СОБСТВЕННОСТИ: ПРОБЛЕМЫ И ПЕРСПЕКТИВЫ
}

\author{
(c) 2019 Михайлов Максим Викторович \\ аспирант кафедры мировой экономики \\ РЭУ им. Г.В. Плеханова, Россия, Москва \\ Начальник юридического отдела ООО «Союзпатент» (sojuzpatent.com), Россия, Москва \\ E-mail: maxim.v.mikhailov@gmail.com \\ ORCID0000-0002-2905-8199
}

В статье содержится исследование роли и места России на мировом рынке промышленной интеллектуальной собственности. На сегодня страна занимает позицию чистого импортера ОИС, даже с учетом реализации военно-коммерческих программ с другими государствами. Сочетание геоэкономических проблем и геополитических вызовов стимулировало разработку национальной стратегии по формированию системы управления интеллектуальными ресурсами Российской Федерации на перспективу на базе имеющегося хозяйственного потенциала страны.

Ключевые слова: интеллектуальная собственность, патент, РСТ, технологический платежный баланс, коэффициент технологической зависимости

Интеллектуальный потенциал нашей страны долгое время оставался гарантией её независимости и развития. Концентрация научно-технического потенциала и средств производства позволили в послевоенное время поднять страну из руин и обеспечить ее обороноспособность. Только СССР и США осуществляли в послевоенное время фундаментальные и прикладные исследования практически по подавляющей части научных направлений. Однако за годы перестройки и реформ национальная наука понесла тяжелые потери. Прежде всего, были стремительно ликвидированы отраслевые научно-исследовательские институты и организации. Практика неоправданного секвестирования академической науки привела к ее запустению. Российская Федерация, имеющая высокий инновационный потенциал и способность создавать собственные знания, имеет реальные возможности выдвинуться на лидирующие позиции в этой области. Успехи военно-промышленного комплекса являются наглядным тому примером.

При анализе роли и места Российской Федерации на мировом рынке технологий, необходимо исходить из того непреложного факта, что количество объектов национальной ИС, способной пройти процедуру регистрации (патентования), стало заметно меньше. Прежде всего, это связано с резким сокращением изобретательской активности, ставшей следствием распада советской системы научно-исследовательских и опытно-конструкторских разработок (НИОКР).
Если до развала СССР в год регистрировалось до 200 тыс. заявок, то в современной России их количество уже не превышает 20-30 тысяч за тот же период. Таким образом, положение дел в сфере национального патентования может лишь с большой долей условности быть сопоставимо с положением в ведущих странах.

Иностранные заявители проявляют особый интерес к патентованию изобретений, прежде всего, в двух наукоемких, капиталоемких, высоко прибыльных и таких перспективных отраслях, как телекоммуникационная, а также производство лекарств и диагностического медицинского оборудования. Относительно перспективными следует отнести также технологии и способы получения химической обработки высокомолекулярных соединений, а также производство композиций и всевозможных реплик на основе подобных соединений. Такой вид производства способен «запустить» перспективные производственно-технологические цепочки с учётом наступающего технологического уклада.

Самые последние наиболее перспективные научные технологии, способные дать импульс качественно новому уровню производств, иностранцы, как правило, не применяют в России. При этом, речь, понятно, не идет об использовании военно-технических разработок. Применение правообладателями гражданских перспективных технологий в других странах также является предметом пристального мониторинга специальных государственных органов. Конечно, 
подавляющая их часть, (например, после принятия закона Бэя-Доуэла в США в 1980 г.) является собственностью американского бизнеса. Но использование подобных технологий за рубежом обставляется большим количеством условий и проверок. На их использование в других странах может быть наложен запрет, инициированный законодательной и исполнительной ветвями власти США. После введения санкций против Российской Федерации эти структуры добились разрыва договоров с российскими партнерами по большому количеству проектов. Часть из них была связана с пионерными американскими технологиями в области шельфового и глубоководного бурения, нефтедобычи в районе вечной мерзлоты, переработки высокосернистой нефти и т.д.

Имеющий в настоящее время место рост числа иностранных заявок на регистрацию изобретений в России можно оценить, прежде всего, как робкие шаги в процессе углубления участия страны в системе международного разделения труда. Подобная процедура оказывается важной, прежде всего, для иностранцев, стремящихся защитить свой бизнес на перспективной территории. Иностранные инвестиции, как правило, не следуют за патентами, а правовая охрана изобретений в России используется исключительно с целью конкурентной борьбы с местными, ло- кальными изготовителями той или иной продукции.

На сегодня страна занимает позицию чистого импортера объектов, даже с учетом реализации военно-коммерческих программ с другими государствами (рис. 1).

В 2018 г. баланс платежей, осуществленных страной за рубеж и полученной прибыли, а также лицензионные платежи составили отрицательную величину в 5,4 млрд. долл. При этом, доля от всякого рода текущих отчислений продавцу лицензии за использование патентов, авторских прав, франшиз и др. виды роялти в объёме экспорта услуг составила 1,4\% (0,876 млрд. долл.), а в суммарном объёме импорта услуг 6,6\% (6,288 млрд. долл.). На этот же период объемы экспорта превосходили объемы импорта объектов интеллектуальной собственности в 7,17 раза. За последние 5 лет в абсолютных цифрах объемы экспорта и импорта объектов интеллектуальной собственности представлены на рис. 2.

При этом показатель доли высокотехнологичных товаров в общем объеме экспорта товаров за последние 5 лет был волатилен, достигнув в 2018 г. 10,9\%. Доля же в импорте росла, достигнув в 2018 г. 67,2\% (табл. 1).

Данные табл. 2 показывают, что решающими контрагентами России в товарообмене ИС выступают страны дальнего зарубежья. Их доля

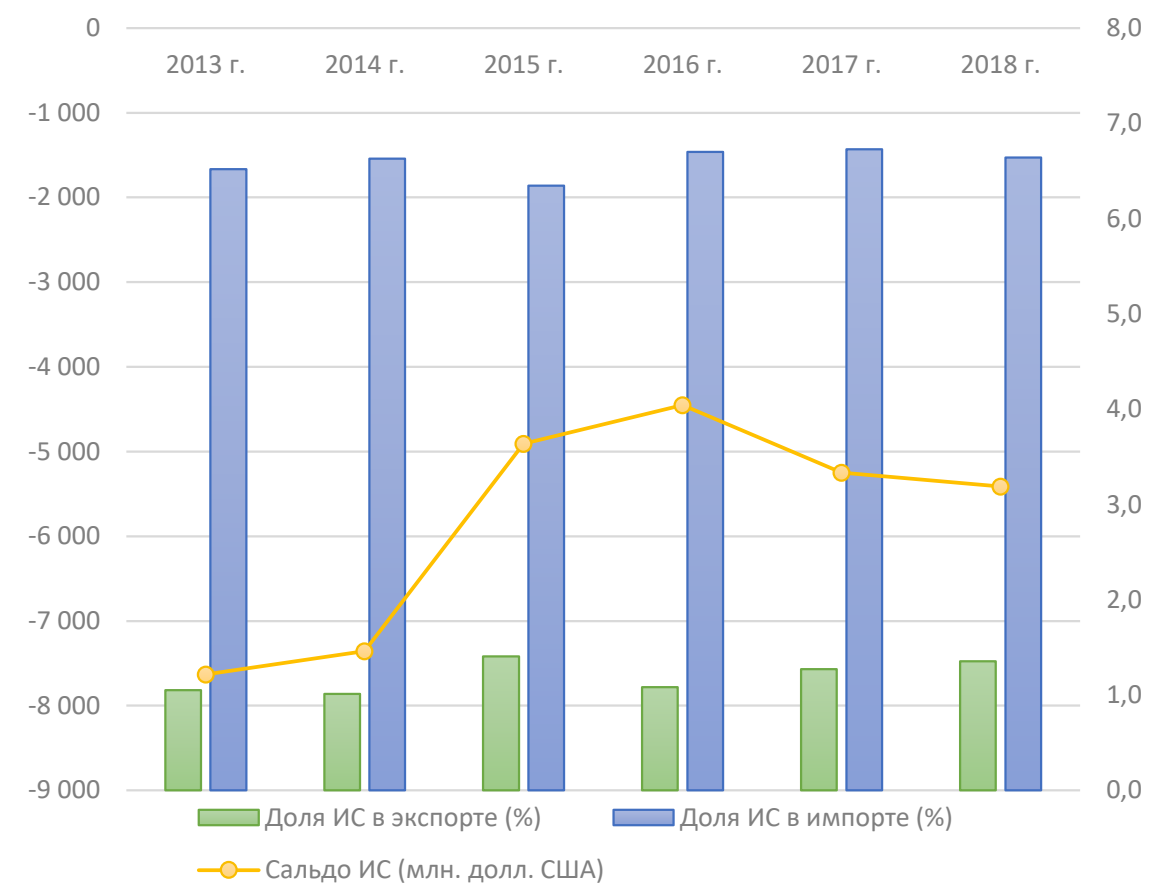

Puc. 1. Доля роялти и лицензионных платежей в экспорте/импорте услуг России в 2013-2018 гг. (\%) и сальдо торговли объектами ИС, млн. долл. Источник: составлено автором на базе данных Центрального банка РФ [9]. 


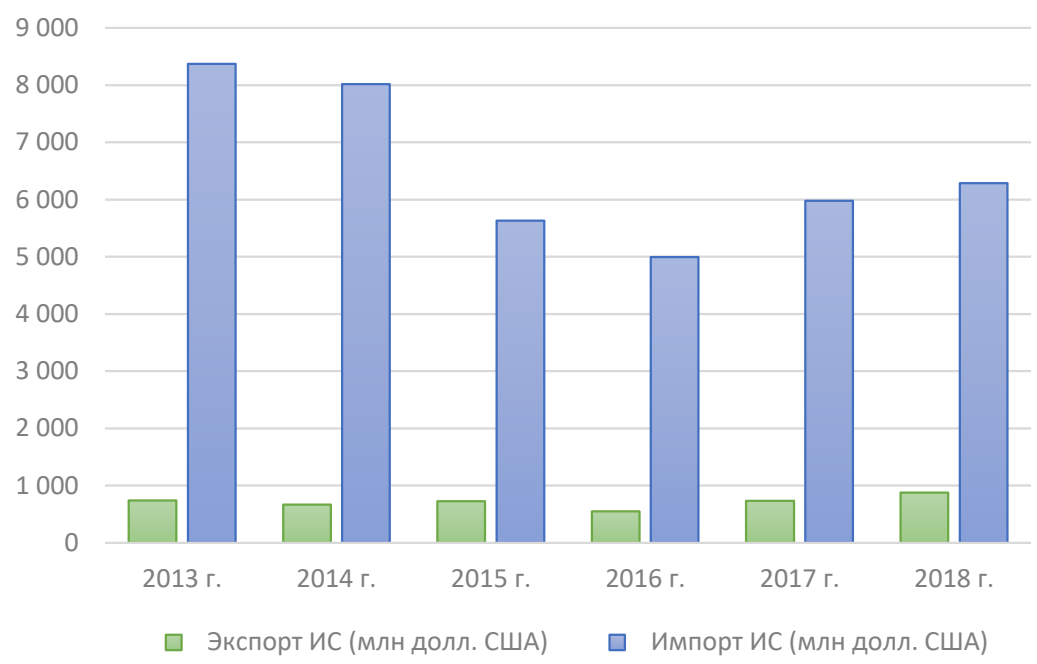

Puc. 2. Объемы экспорта и импорта интеллектуальной собственности России, млн. долл. Источник: составлено автором на базе данных Центрального банка РФ [9].

Таблица 1. Доля высокотехнологичных товаров во внешней торговле России,\%

\begin{tabular}{|l|c|c|c|c|c|c|}
\hline & 2013 & 2014 & 2015 & 2016 & 2017 & 2018 \\
\hline $\begin{array}{l}\text { Доля высокотехнологичных товаров } \\
\text { в общем объеме экспорта России }\end{array}$ & 10,2 & 10,0 & 12,8 & 14,5 & 13,7 & 10,9 \\
\hline $\begin{array}{l}\text { Доля высокотехнологичных товаров } \\
\text { в общем объеме импорта России }\end{array}$ & 62,4 & 61,2 & 58,7 & 61,3 & 68,4 & 67,2 \\
\hline
\end{tabular}

Источник: составлено автором по данным Росстата [8].

Таблица 2. Партнеры России по торговле объектами ИС

\begin{tabular}{|c|c|c|c|c|c|c|}
\hline Год & Страны & $\begin{array}{c}\text { Баланс тор- } \\
\text { говли ИС, } \\
\text { млн. долл. }\end{array}$ & $\begin{array}{c}\text { Экспорт, млн. } \\
\text { долл. }\end{array}$ & $\begin{array}{c}\text { Импорт, млн. } \\
\text { долл. }\end{array}$ & $\begin{array}{c}\text { Доля в импор- } \\
\text { те ИС (\%) }\end{array}$ & $\begin{array}{c}\text { Доля в экс- } \\
\text { порте ИС (\%) }\end{array}$ \\
\hline \multirow{3}{*}{2013} & Всего & -7633 & 738 & 8371 & 100,0 & 100,0 \\
\hline & Дальнее зарубежье & -7729 & 576 & 8306 & 99,2 & 78,0 \\
\hline & СНГ & 96 & 162 & 65 & 0,8 & 22,0 \\
\hline \multirow{3}{*}{2014} & Всего & -7356 & 666 & 8021 & 100,0 & 100,0 \\
\hline & Дальнее зарубежье & -7481 & 491 & 7972 & 99,4 & 73,7 \\
\hline & СНГ & 126 & 175 & 50 & 0,6 & 26,3 \\
\hline \multirow{3}{*}{2015} & Всего & $-4907,68$ & 726,17 & 5633,85 & 100,0 & 100,0 \\
\hline & Дальнее зарубежье & $-5075,83$ & 528,74 & 5604,57 & 99,5 & 72,8 \\
\hline & $\mathrm{CH \Gamma}$ & 168,15 & 197,43 & 29,28 & 0,5 & 27,2 \\
\hline \multirow{3}{*}{2016} & Всего & $-4449,61$ & 547,76 & 4997,36 & 100,0 & 100,0 \\
\hline & Дальнее зарубежье & $-4525,69$ & 451,28 & 4976,97 & 99,6 & 82,4 \\
\hline & СНГ & 76,08 & 96,48 & 20,40 & 0,4 & 17,6 \\
\hline \multirow{3}{*}{2017} & Всего & $-5246,97$ & 732,80 & 5979,77 & 100,0 & 100,0 \\
\hline & Дальнее зарубежье & $-5320,61$ & 634,74 & 5955,35 & 99,6 & 86,6 \\
\hline & $\mathrm{CH \Gamma}$ & 73,63 & 98,05 & 24,42 & 0,4 & 13,4 \\
\hline \multirow{3}{*}{2018} & Всего & $-5412,07$ & 876,10 & 6288,17 & 100,0 & 100,0 \\
\hline & Дальнее зарубежье & $-5484,26$ & 767,76 & 6252,01 & 99,4 & 87,6 \\
\hline & СНГ & 72,19 & 108,34 & 36,16 & 0,6 & 12,4 \\
\hline
\end{tabular}

Источник: составлено автором по данным ЦБ РФ [9]. 
в объеме национального импорта ИС близка к 100\% (в 2018 г.-99,4\%, или 6,3 млрд. долл., а в экспорте $-87,6 \%$ (768 млн. долл). Это, в целом, отражает реальности положения дел в этом секторе, даже если не принимать во внимание санкционные меры Запада. Они носят откровенно дискриминационный характер, в связи с чем ряд англосаксонских стран был вынужден расторгнуть инновационные сотрудничество в ряде важных проектов России. Сложности геополитической ситуации наложили отпечаток на сотрудничество России со странами СНГ. Для него также характерен синусоидальный период взлетов и падений (табл. 2).

Анализ данных, касающихся международного обмена объектами интеллектуальной собственности, невозможен без учета российских национальных особенностей статистического учета результатов интеллектуальной деятельности и приравненных к ним средств индивидуализации. Как известно, формирование российской статистики внешней торговли объектами интеллектуальной собственности осуществляют такие ключевые национальные институты, как Федеральная служба государственной статистики (Росстат) и Центральный банк Российской Федерации.

Российское статистическое ведомство достаточно «прозрачное» учреждение. Оно аккумулирует и предоставляет публичный доступ к Соглашениям, а также Статистике международной торговли технологиями Российской Федерации. Именно эти данные использует Организация экономического сотрудничества и развития (ОЭСР) при формировании статистических данных обмена технологиями, в том числе технологического платежного баланса (Technology Balance of Payments, OECD Main Science and Technology Indicators) [19].

Контекст российских соглашений включают, как определенный ряд «охраняемых», казанных в статье 1225 ГК РФ, объектов интеллектуальной собственности, так и «неохраняемые» [12]. Перечень Росстата не содержит охраняемые нетехнологические объекты интеллектуальной собственности, например, объекты авторских и смежных прав. В целом, данные Росстата и ОЭСР свидетельствуют о сопоставимой и даже близкой методологической базе, используемой обеими организация, в оценке показателей рынка технологий, но не рынка объектов интеллектуальной собственности как таковых (оборот са- мих объектов интеллектуальной собственности более точно отражает статистика платежного баланса ЦБ РФ [9] и Всемирного банка [5]). К сожалению, в настоящее время (2019 г.) ОЭСР публикует статистику по технологическому платежному балансу только за 2015 г. [7] Минусом контрольных данных ОЭСР является отсутствие статистики по технологическому балансу континентального Китая. На сайтах Росстата [8] и Минэкономразвития [6] статистика по России представлена до 2017 г. включительно.

Методологическая база ОЭСР, отражающая торговлю интеллектуальной собственностью имеет, свои особенности. Определенный интерес для исследования представляют статистические ряды, которые составляет основу технологического платёжного баланса исследуемой страны. Статистика ОЭСР формирует в его рамках четыре группы категорий. Первую группу составляет трансфер технологий, который отражает объем сделок, связанных с трансграничными передачами патентов, лицензий, ноу-хау. Вторая, фиксирует объемы сделок связанных с разработками в сфере дизайна, товарного знака, промышленного образца и т.п. (последняя опция осуществляется посредством прямой продажи, или предоставление права использования). Третья, учитывает объём предоставленных технологических услуг, включая организацию и проведение НИОКР, а также подготовку специалистов, обслуживание техники, организацию исследований. В условиях информационной революции среди наиболее востребованных видов заметную роль стали играть компьютерные, инженерные и прочие услуги, связанные с получением, обработкой, хранением, реализацией накопленной информации. Четвёртая связана с защитой правообладателей, внедряющих результаты индустриальных новшеств за рубежом, прежде всего, в развивающихся странах [3, С. 33].

Технологический платежный баланс отражает роль, место и принципы функционирования интеллектуального капитала страны в мировой экономике и строится по подобию внешнеторгового баланса государства. Суммарный объем его дебета и кредита позволяет, в конечном итоге, оценить государство на рынке технологических новинок. Чем больше её положительное сальдо, тем выше положение занимает страна среди технологически развитых стран.

Подчеркивая необходимость профессионального сотрудничества различных наци- 
ональных институтов в практике создания достоверной источниковедческой базы надо выделить роль Центрального банка Российской Федерации (ЦБ РФ). Его публикации платёжного баланса Российской Федерации [9] включают сведения о трансграничных операциях с объектами интеллектуальной собственности, которые методологически рассчитываются на основе VI издания Руководства по платежному балансу и международной инвестиционной позиции МВФ (РПБ 6). Общий результат операций по объектам интеллектуальной собственности отражается в разделе «Плата за пользование интеллектуальной собственностью» [13], где, собственно, и отображаются сделки по передаче прав на объекты интеллектуальной собственности (товарные знаки, изобретения и т.п.), а также фиксируется движение «непроизведенных нефинансовых активов».

Схематически, порядок отражения операций с интеллектуальной собственностью в платёж- ном балансе Российской Федерации, представлен в табл. 3. Платежи при отчуждении объектов ИС и прав на них учитываются на счёте операций с капиталом. Эта статистика, как отмечалось, также передается во Всемирный банк для публичного размещения [5].

Статистика торговли объектами интеллектуальной собственности по методологии, используемой центральными банками России, Китая, США, Великобритании, Германии и Японии, представлена на рис. 3. Из неё следует, что, сальдо торговли объектами интеллектуальной собственности у России и Китая на протяжении последних более чем 10 лет является отрицательным.

Вместе с тем, если взять такой показатель, как количество подаваемых патентных заявок, то в абсолютных лидерах здесь отмечены резиденты Китая (рис. 4).

Как известно, система ключевых показателей роли страны на международном рынке ин-

Таблица 3. Порядок отражения операций с интеллектуальной собственностью в платёжном балансе Российской Федерации

\begin{tabular}{|l|l|l|}
\hline Статья ПБ РФ & $\begin{array}{l}\text { Торговля услугами: «плата за пользование интеллек- } \\
\text { туальной собственностью» }\end{array}$ & $\begin{array}{l}\text { Движение капитала: «непроизведен- } \\
\text { ные нефинансовые активы }\end{array}$ \\
\hline Тип сделки & $\begin{array}{l}\text { Передача права использования объекта интеллекту- } \\
\text { альной собственности }\end{array}$ & $\begin{array}{l}\text { Отчуждение прав на объекты интел- } \\
\text { лектуальной собственности }\end{array}$ \\
\hline $\begin{array}{l}\text { Результат } \\
\text { сделки }\end{array}$ & $\begin{array}{l}\text { Временное использование объекта интеллектуальной } \\
\text { собственности (в том числе ноу-хау) по лицензионно- } \\
\text { му соглашению, договору франчайзинга }\end{array}$ & $\begin{array}{l}\text { Смена правообладателя соответству- } \\
\text { собственнокта интеллектуальной }\end{array}$ \\
\hline
\end{tabular}

Источник: составлено автором на основе данных ЦБ РФ и ГК РФ.

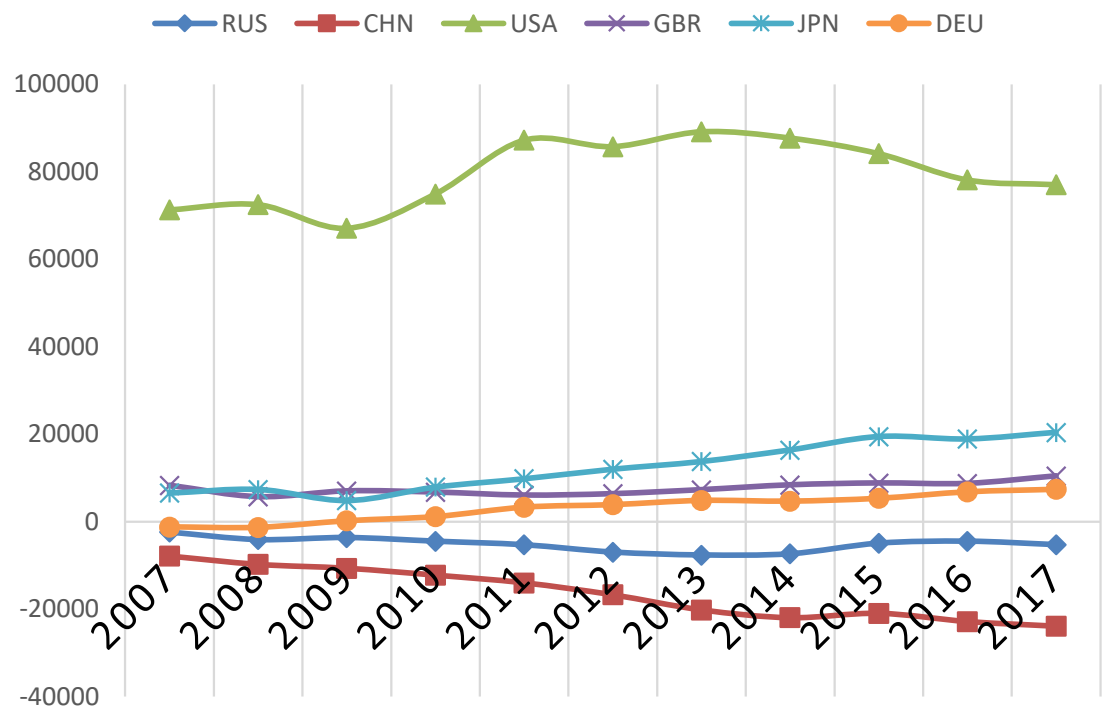

Puc. 3. Сальдо торговли объектами интеллектуальной собственности, млн. долл. Источник: составлено автором на основе данных с сайта Всемирного банка [5]. 


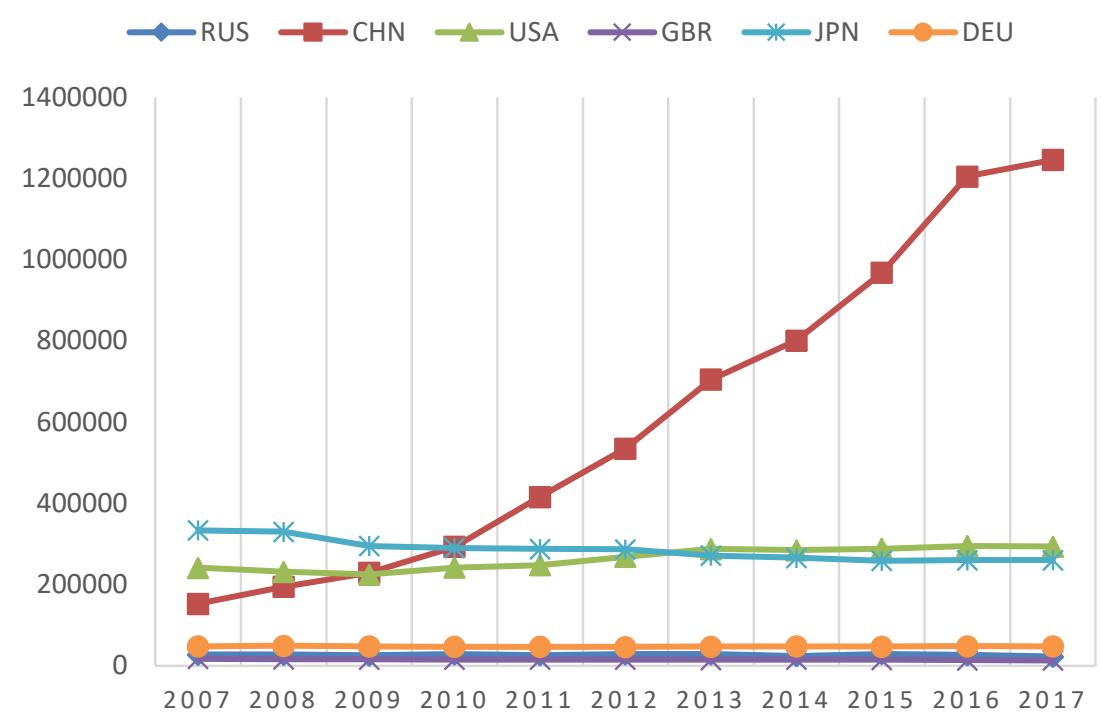

Puc. 4. Количество патентных заявок со стороны резидентов

Источник: составлено автором на основе данных с сайта Всемирного банка [5]

теллектуальной собственности определяется многофакторными показателями, а также обобщенным уровнем, что страна достигает с помощью изобретательской активности. Чаще всего эти результаты способны выступить в качестве потенциальных технологических активов или реальных роялти. В конечном итоге, именно они при помощи прямых и обратных производственных связей отражают место научно-технологической сферы страны и ее влияние на мировую экономику. Количество зарегистрированных заявок является важнейшим показателем уровня ИС конкретного государства. Степень патентной активности выражается соотношением количества патентов национальных изобретателей на 10 тыс. её жителей. Согласно данным Роспатента, по этому показателю Российская Федерация отстаёт от развитых стран в 5-18 раз [2].

Сложившееся положение дел во многом является результатом негативной ситуации в экономике России в 1990-х годах. В определенной степени данную систему обстоятельств можно квалифицировать, как чрезмерно затянувшийся переходный этап, что переживает Российская Федерация.

На этой основе сложился известный парадокс. Рыночные отношения в условиях переходной экономики были ориентированы на дальнейшее углубление участия страны в системе международных экономических отношений, подкрепляясь всё большим числом законов, указов и постановлений. В то время как профессиональная активность российских разработчиков перспективных научно-технических предложений, исчисляемая количеством регистрируемых изобретений, снижалась.

B XXI веке в сфере управления научной деятельностью страны произошел ряд подвижек. В качестве стратегического элемента управления была продолжена кооперация высшей школы и государственных научных учреждений. Организации, которые на конкурсной кооперационной основе создавали высокотехнологичное производство [10], а также инновационную инфраструктуру, получали финансирование из разных источников, преимущественно государственных. Это создавало базу поддержки малого предпринимательства в федеральных вузах, которые, в свою очередь, формировали инновационную среду для хозяйствующих субъектов [11].

Кроме фиксированной доли внутреннего инвестирования затрат на исследования и разработки специальным решением определялся объём финансирования НИОКР для ведущих университетов страны (25 млрд. рублей к 2018 г.). В 2013 году осуществлена реорганизация и объединение государственных академий наук. Федеральный закон определил правовое положение и функции обновленной РАН, установил порядок финансового обеспечения её деятельности. Наряду с ответственностью за формирование государственной научно-технической политики на неё возложена задача проведения фундаментальных исследований на долгосрочный период [18]. Координация работы в области научно-технического развития и образования поручена 
Совету при Президенте РФ. Его ключевая функция - определение приоритетных направлений и инфраструктуры междисциплинарных исследований, а также механизмы поддержки научно-образовательной сферы [15]. Логическим продолжением процесса стало создание Российского научного фонда (РНФ). В качестве его ключевых компетенций определена поддержка фундаментальных научных исследований, а также подготовка коллективов, занимающих лидирующие позиции в перспективных областях науки [17]. При этом система подготовки научных и научно-педагогических кадров была выделена в специальную целевую программу. Она предполагала, как систему совершенствования подготовки, так и закрепления кадров высокой квалификации в научно-образовательной сфере. Высокая международная мобильность кадров рассматривается как непременное условие повышения конкурентоспособности страны на мировом рынке [16].

Осознание растущих внешних угроз обусловило принятие специальной среднесрочной государственной программы. Создание в её рамках конкурентоспособного сектора научно-исследовательских и опытно-конструкторских работ (НИОКР), что открывает возможность адекватно ответить на внешние вызовы, и стать условием для процесса технологической модернизации национальной экономики, было отнесено к национальным приоритетам. Данное обстоятельство не утратило свою актуальность и в современных реалиях [1].

В качестве информационного элемента стимулирования рынка интеллектуальной собственности с 2014 г. введена практика обязательного учёта результатов НИОКР. Это не только инструмент управления результатами исследований и разработок на всех стадиях, но и площадка для взаимодействия промышленности и науки. Количество научных проектов, учтённых только за 2015 год, превысило 10 тысяч, а количество поисковых запросов в этой системе превышало 100 тысяч в месяц [4]. В результате за 2015 г. на 70\% выросло общее количество внедренных результатов интеллектуальной деятельности.

В настоящее время одной из главных проблем остается крайне незначительное количество международных охранных документов на российские изобретения. По данным Всемирной организации интеллектуальной собственности
(ВОИС), в 2016 г. Россия находилась на седьмом месте по количеству национальных патентных заявок (41,6 тыс. ед.). На этом фоне, среди её основных конкурентов, особенно заметна активность: США (589 тыс. ед.), Японии (319 тыс.), Республики Корея (213,7 тыс.), ФРГ (66,9 тыс.), Индии (45,7 тыс.). При этом по числу международных заявок в рамках Договора о патентной кооперации (Patent Cooperation Treaty, PCT) у нашей страны лишь 25-е место. Импорт интеллектуальной собственности в 11 раз превышает её экспорт. Всё это свидетельствует о достаточно скромном месте страны на мировом рынке высоких технологий.

Одновременно за 2000-е гг. отмечен ряд негативных тенденций, унаследованных от 1990-х гг. Одним из индикаторов неблагополучия выступает рост коэффициента технологической зависимости страны (КТЗ). Ещё до применения к России санкций, его величина выросла с $0,3 \%$ в 2004 г. до 0,55\% в 2015 г. Такая ситуация противоречит устоявшейся в мировой практике тенденции, когда технологически развивающиеся государства снижают аналогичный показатель. Особенно благоприятно тенденция складывается для Китая, где величина КТЗ за этот период снизилась с 0,98 до 0,14. В большинстве развитых стран (Япония, ФРГ, Республика Корея) он не превышает 0,23-0,28\%.

Коэффициент технологической зависимости

$$
\mathrm{K}_{\text {т3 }}=\frac{\boldsymbol{N}_{\text {ин.3 }}}{\boldsymbol{N}_{\text {от.3 }}} \times \mathbf{1 0 0} \%
$$

где $N_{\text {ин.3 }}-$ количество патентов, выданных иностранным заявителям

$N_{\text {от.3 }}-$ количество патентов, выданных отечественным заявителям

Кроме того, до сих пор ещё существует практика, вследствие которой НИОКР в нашей стране развиваются не столько исходя из экономических потребностей и целесообразности хозяйственного развития (предприятия, отрасли, государства), сколько вследствие административных требований к организациям-разработчикам наукоемких технологий, в том числе с целью повышения эффективности предприятия.

Сочетание геоэкономических проблем и геополитических вызовов стимулировало разработку национальной стратегии по формированию системы управления интеллектуальными ресурсами Российской Федерации на стратегиче- 
скую перспективу с учетом имеющегося хозяйственного потенциала страны. Технологическая независимость, обеспечивающая устойчивое, динамичное и сбалансированное развитие государства на долгосрочную перспективу, служит основой прогнозируемого процесса. Способы реализации программы, основанной на эффективном использовании интеллектуальных, материальных и финансовых ресурсов определяет «Стратегия научно-технологического развития Российской Федерации» [14] (далее Стратегия). Решение задач, изложенных в Стратегии, призвано существенным образом трансформировать взаимосвязь науки и технологии, стать ключевым фактором развития общества.

Технологическая реконструкция традиционных отраслей хозяйства направлена на обеспечение роста производства продукции, пользующейся на международном рынке устойчивым спросом. Под этим понимается не только процесс внедрения технологии, о существовании которых ещё 5-10 лет тому назад не было известно. Извлечение дополнительных ресурсов на отработанных месторождениях и приисках естественная реакция исследователей на грядущую перспективу исчерпаемости определенных их видов. Параллельно этому, на основе использования разрабатываемых технологий, ставится задача существенно увеличить долю высокотехнологичных производств, в т.ч. в рамках международных проектов, включая создание и использование уникальных научных установок класса мегасайенс. Кооперационные НИОКР должны стать основой совокупности международных сопряженных (гибких) производств, располагающих единым техническим уровнем. Перспективы освоения результатов VI Технологического уклада, согласно прогнозам, дадут возможность освоить процесс конструирования материалов и организмов с заранее заданными свойствами. Массовое освоение перспективных технологий обеспечит доступ страны на новые рынки научно-технических товаров и, как следствие, обеспечит конкурентоспособность государства в мире.

Реализация Стратегии - многофакторный процесс. Она содержит ключевые принципы двухэтапной государственной научно-технической политики, которая базируется на бюджетной системе Российской Федерации.

Первый этап реализации Стратегии (20172019 гг.) определил основные административные, финансовые и законодательные механизмы, действие которых предполагает конвергенцию различных направлений общественной жизни страны. Стимулирование условий для роста активности научной, научно-технической и инновационной деятельности сочетается с решением социальных и гуманитарных вопросов.

Комплексной задачей второго этапа стратегии (2020-2025 гг.) является формирование технологий, способных дать ответ на глобальные вызовы настоящего и будущего. Параллельно ставится задача активизации коммерческих результатов инновационной деятельности с учетом требований устойчивого развития.

Развитие отраслей хозяйства, основанных в т.ч. на природоподобных технологиях, технологическое импортозамещение, стимулирование экспорта инноваций является комплексной целью государственной политики, позволяющей осуществить ре-индустриализацию нашей страны.

\section{Библиографический список}

1. осударственная программа Российской Федерации «Научно-технологическое развитие Российской Федерации», утверждена Постановлением Правительства Российской Федерации от 29 марта 2019 г. № 377 // Собрание законодательства РФ, 15.04.2019, № 15 (часть III), ст. 1750.

2. Ежегодные отчеты Роспатента / URL: https://rupto.ru/ru/about/reports (дата обращения 15.09.2019 г.)

3. Лихачев В.А. Международный трансфер технологий: основные тенденции и позиции России // Российский внешнеэкономический вестник.-2017. № 10.- С. 29-43.

4. О государственной политике в сфере интеллектуальной собственности. Заседание президиума Совета при Президенте Российской Федерации по модернизации экономики и инновационному развитию России, 17 февраля 2015 г. [Электронный ресурс]. - Режим доступа: http://government.ru/news/16924/ (дата обращения 15.09.2019 г.)

5. Официальный сайт Всемирного банка, статистический раздел / URL: https://data.worldbank.org/topic/ science-and-technology (дата обращения 15.09.2019 г.) 
6. Официальный сайт Минэкономразвития России, статический раздел / URL: http://gasu2.ru/taxonomy/ term/37127 (дата обращения 15.09.2019 г.)

7. Официальный сайт ОЭСР, статистический раздел / URL: https://stats.oecd.org/Index.aspx? DataSetCode=MSTI PUB (дата обращения 15.09.2019 г.)

8. Официальный сайт Федеральной службы государственной статистики / URL: https://www.fedstat.ru/organiz ations/?expandId=1292993\#fpsr1292993 (дата обращения 15.09.2019 г.)

9. Официальный сайт Центрального банка Российской Федерации, статистический раздел / URL: https://www. cbr.ru/statistics/? PrtId=svs (дата обращения 15.09.2019 г.)

10. Постановление Правительства РФ от 09.04.2010 № 218 «Об утверждении Правил предоставления субсидий на развитие кооперации российских образовательных организаций высшего образования, государственных научных учреждений и организаций реального сектора экономики в целях реализации комплексных проектов по созданию высокотехнологичных производств в рамках подпрограммы «Инфраструктура научной, научно-технической и инновационной деятельности» государственной программы Российской Федерации «Научно-технологическое развитие Российской Федерации» // Собрание законодательства РФ, 19.04.2010, № 16, ст. 1905.

11. Постановление Правительства РФ от 09.04.2010 № 219 «О государственной поддержке развития инновационной инфраструктуры в федеральных образовательных учреждениях высшего профессионального образования» // Собрание законодательства РФ, 19.04.2010, № 16, ст. 1906.

12. Приказ Федеральной службы государственной статистики от 13.11.2017 № 750 «О внесении изменений в Указания по заполнению формы федерального статистического наблюдения № 1-лицензия «Сведения о коммерческом обмене технологиями с зарубежными странами (партнерами)», утвержденные приказом Росстата от 26.12.2014 № 725» / Режим доступа URL: http://www.gks.ru/bgd/free/b08_26/IssWWW.exe/Stg/ d07/\%D0\%BF\%D1\%80\%D0\%B8\%D0\%BA\%D0\%B0\%D0\%B7\%20\%E2\%84\%96750_131117.docx (дата обращения 15.09.2019 г.)

13. Руководство по платежному балансу и международной инвестиционной позиции МВФ (РПБ6) / Режим доступа URL: https://www.cbr.ru/statistics/credit_statistics/bop/meth_com_bop.pdf (дата обращения 15.09.2019 г.)

14. Указ Президента Российской Федерации от 01.12.2016 г. № 642 «О Стратегии научно-технологического развития Российской Федерации» // Собрание законодательства РФ, 05.12.2016, № 49, ст. 6887.

15. Указ Президента РФ от 25.10.2013 № 803 «Вопросы Совета при Президенте Российской Федерации по науке и образованию» // Собрание законодательства РФ, 28.10.2013, № 43, ст. 5543.

16. Федеральная целевая программа «Научные и научно-педагогические кадры инновационной России» на 2014-2020 годы, утверждена Постановлением Правительства РФ от 21.05.2013 № 424 // Собрание законодательства РФ, 03.06.2013, № 22, ст. 2808.

17. Федеральный закон от 02.11.2013 № 291-Ф3 «О Российском научном фонде и внесении изменений в отдельные законодательные акты Российской Федерации» // Собрание законодательства РФ, 04.11.2013, № 44, ст. 5630.

18. Федеральный закон от 27.09.2013 № 253-Ф3 «О Российской академии наук, реорганизации государственных академий наук и внесении изменений в отдельные законодательные акты Российской Федерации» // Собрание законодательства РФ, 30.09.2013, № 39, ст. 4883.

19. Technology Balance of Payments, OECD Main Science and Technology Indicators / URL: https://www.oecd-ilibrary. org/science-and-technology/main-science-and-technology-indicators_2304277x (access date: 15.09.2019) 